\title{
The muscle - fat duel or why obese children are taller? Dina Ralt*
}

\author{
Address: Izun \& Tmura, Integrative Health Inst. 6 Nezach Israel st. Tel Aviv, 64352, Israel \\ Email: Dina Ralt* - Izun.Tmura@gmail.com \\ * Corresponding author
}

Published: I3 December 2006

BMC Pediatrics 2006, 6:33 doi:10.|| 86//47|-243|-6-33
Received: 14 June 2006

Accepted: 13 December 2006

This article is available from: http://www.biomedcentral.com/I47I-243I/6/33

(c) 2006 Ralt; licensee BioMed Central Ltd.

This is an Open Access article distributed under the terms of the Creative Commons Attribution License (http://creativecommons.org/licenses/by/2.0), which permits unrestricted use, distribution, and reproduction in any medium, provided the original work is properly cited.

\begin{abstract}
Background: Obesity the epidemic of our times appears to be a problem that is easy to resolve: just eat less and move more. However, this very common condition has turned out to be extremely troublesome, and in some cases even irreversible.
\end{abstract}

Methods: The interplay between less muscle and more fat tissue is discussed from physiological perspectives with an emphasis on the early years of childhood.

Results: It is suggested that the coordinated muscle-fat interactions lead to a fluctuating exchange economy rate. This bodily economic decision, slides between thrift (more fat) and prodigal (more muscle) strategies. The thrift strategy results not only in obesity and less physical activity but also in other maladies which the body is unable to manage.

What leads to obesity (less muscle, more fat) might be very difficult to reverse at adulthood, prevention at childhood is thus recommended.

Conclusion: Early recognition of the ailment (low muscle mass) is crucial. Based on studies demonstrating a 'rivalry' between muscle build-up and height growth at childhood, it is postulated that among the both taller and more obese children the percentage of children with lower muscle mass will be higher.

A special, body/muscle-building gymnastics program for children is suggested as a potential early intervention to prevent the ill progress of obesity.

\section{Text}

The Health Survey for England warns that by 2010, if nothing is done, $19 \%$ of boys and $22 \%$ of girls aged two to 15 will be obese [1]. Larger body size is not the main problem of obesity [2], the problems are the numerous accompanying maladies [3-5].

The spreading of the obesity epidemic, termed Globesity $[6,7]$, is pointing to a very distressing situation - obesity not only seems irreversible but its incidence continues to rise. Though adenovirus showed association with obesity
[8] more basic interactions point to a non-viral physiological complexity of gaining weight. The increased calorie intake and decreased physical activity, allied with obesity, appear to be the result of a bodily economic strategy rather than just the result of behavioral aberration [9].

What is the nature of this physiological strategy (i.e. exchange economy rates)? It has many attributes but this commentary will focus on the interplay between muscle and fat tissue. Interplay that leads the body to economic decisions fluctuating between thrift and prodigal strate- 
gies. Consider for example, thermogenesis [10] or Non Exercise Activity Thermogenesis [11] as indirect parameters for such an exchange economy rate.

Muscles are amongst the costliest tissues of the body to maintain [12-14], therefore under certain conditions muscle 'deficiency' could be beneficial (conserving muscle energy may be advantageous, as the saved energy can actuate other functions). It is thus no wonder that built-up muscles rapidly revert to their original size unless trained or used constantly [15-17]. Muscle activity induces prodigal strategy which enables not only its working but also allows other bodily functions to operate, resulting in good health and positive mood. On the other hand fat accumulation occurs when food shortage is being expected or when excess food makes physical activity unnecessary. Fat accumulation needs extra available energy thus arresting energy expenditure is always associated with the weight increase. The more fat tissue available, the greater is its power to induce thrift strategy resulting not only in obesity and in decline of physical activity but also in other untreated health problems.

The aim of this commentary is to exhibit the contradictory physiological effects of the muscle and the fat tissue and to show how their integrated capacities determine our wellness.

Please note that fat accumulation will naturally overcome muscle buildup as without additional effort, access fat but not access muscle will be maintained. Overabundance of food was (until recently) rare and thus it is no wonder that no evolutionary tactics were developed to handle health mischiefs of excess food or lack of physical activity. Our natural tendency (based on long history of food shortage) is to save energy whenever possible, for example in walking we naturally choose the pace that minimizes energy cost per distance, even when this strategy requires a greater relative aerobic effort [18] (see also next paragraph).

Experiments with animals have shown that even the expression of a genetic predisposition to high physical performance strongly depends upon the environment experienced early in life. Fully fed lizards experienced a marked reversal of performance within only one month after birth [19]. The lizards take advantage of the excess food and save muscles activity. On the other hand, mice pups whose mothers had received 30\% less energy during pregnancy were born underweight. These pups experience the increase in blood leptin a week earlier than usual, and when they receive a high-fat diet they gain weight faster than their counterparts born to normally-fed mothers [20]. These results indicate the ease with which fat is favored over muscle in the animal kingdom. The same trends of energy savings (less muscle, more fat) under deprivation were also observed in humans. Babies who were conceived during the Dutch famine of 1944-1945 showed higher rates of obesity at age 19 and age 50 than the rates of those conceived before or after that challenging period [21]. This suggests that babies who receive poor nutrition in the womb, 'expect' to face food shortages after birth as well, and their metabolism will be regulated to be especially thrifty with the calories they receive. When such individuals eat the rich diets typical of today's developed countries, they quickly become overweight. This obesity, which is part of the natural developmental plasticity [20], becomes inevitable and accentuated with lower muscle mass. Lower muscle mass can be the result of lack of physical activity, genetics and/or overeating and is observed in the more rapid growth of nowadays children. Indeed averaged body mass index is higher in tall than in short children $(7,23,24)$. This is the opposite of a higher muscle mass condition, which results in slower growth rate. Gymnasts for example, experience growth spurts in height that occur approximately 1-2 years later than non-athletic adolescents [25-27]. The correlation between obesity and height has been established in many countries. A French study showed that the increase in the prevalence of obesity is indeed accompanied by a global trend of accelerated growth [28] and a study in Chile has shown that obese preschool children were four centimeters taller than the normal weight children [29]. The interplay between growth and obesity represents a physiological adaptive trait. This trait enables the body to choose between investing energy in growth or saving energy for storage.

Obesity hormones indeed do affect growth. It has been shown that tall and obese children exhibit variation in the ghrelin gene [30], and leptin was shown to stimulate growth even in the presence of caloric restriction [31].

\section{What can be done?}

The ease with which many individuals gain weight suggests that the energy homeostasis system in the body is inherently biased toward weight gain [32] and thrift strategy. Moreover, in many mammals, energy stored in adipose tissue is held relatively constant [33]. These and other findings, like the many-fold regulatory materials $[34,35]$ excreted by fat cells, suggest that fat cells are not inert fat storage depots but rather active, manipulative cells in 'dialogue' with muscles and other tissues $[36,37]$. These fat tissue tactics may be a burden to any obesity solution, and are especially severe for those with low muscle mass and hence less 'muscle-negotiation' capability. Avoiding fat storage as early as possible, before it starts to induce further fat accumulation is mandated [38]. The difficulty in losing weight was stated by the U.S. Preventive Services Task Force, which found insufficient evidence for the effectiveness of behavioral counseling or other preventive interventions with overweight children [39]. 
A special effort should be directed toward defining the children with initial lower muscle mass as their obesity might be very difficult to combat later. Besides tallness and obesity it may be interesting to look for additional parameters such as ghrelin variations [30], bone density [40] or a measure of diet-induced thermogenesis [41] that might discern the lower muscle mass group within the general obesity group.

As suggested, it is the muscle activity that can avoid a very difficult to reverse obesity and ill health, indeed the underappreciated role of muscles in health and disease has already been observed [42]. Not very many studies have directly tested the great benefits of exercise on children [43]. However, studies concerning strength training are starting to accumulate [44-47]. Such a recent study showed that obese children who participated in a weighttraining group, experienced a significant increase in muscle strength, while the control group had no such increase. In the same study, the fat mass of the children in the weight-training group did not change during the ten-week course of the study, while the children in the control group gained an average of more than 2.5 pounds of fat during the same period [48].

If muscles are the main health negotiators with the fat tissue, a body/muscle-building gymnastics program for children, is required to help prevent the ill progress of obesity. Investigations to determine the influence of resistance exercise on child obesity are thus needed. As stated, such studies are indeed starting to accumulate and some, more intricate, reveal interesting results. In young women for example, it was shown that resistance exercise increased a spectrum of growth hormone molecules [49].

The resistance exercise approach can prevent or decrease weight gain early, helping all obese children and especially those with low muscle mass.

How about starting to think on muscles [50]?

\section{References}

I. Forecasting obesity to 2010 The Health Survey for England, prepared for the Department of Health, 25 August 2006 [http:www.dh.gov.uk/PublicationsAndStatistics/Publications/ Publications Statistics/PublicationsStatisticsArticle/fs/ en?CONTENT ID=4/38630\&chk=XVZ/60].

2. Li R, Tsaih SW, Shockley K, Stylianou IM, Wergedal J, Paigen B, Churchill GA: Structural model analysis of multiple quantitative traits. PLoS Genet 2006, 2(7):el I4.

3. Dietz WH, Robinson TN: Clinical practice. Overweight children and adolescents. N Engl J Med 2005, 352:2100-2109.

4. Han TS, Sattar N, Lean M: ABC of obesity. Assessment of obesity and its clinical implications. BMJ 2006, 333(7570):695-698.

5. Hughes P, Murdock DK, Olson K, Juza R, Jenkins K, Wegner A, Hendricks B: School children have leading risk factors for cardiovascular disease and diabetes: the Wausau SCHOOL project. WMJ 2006, I05(5):32-39.
6. WHO Global Database on Body Mass Index an interactive surveillance tool for monitoring nutrition transition [http://www.who.int/bmi/ index.jsp].

7. Freedman DS, Khan LK, Mei Z, Dietz WH, Srinivasan SR, Berenson GS: Relation of childhood height to obesity among adults: the Bogalusa Heart Study. Pediatrics 2002, I09:e23.

8. Rathod M, Vangipuram SD, Krishnan B, Heydari AR, Holland TC, Dhurandhar NV: Viral mRNA expression but not DNA replication is required for lipogenic effect of human adenovirus Ad36 in preadipocytes. Int J Obes (Lond) in press. 2006, May 2

9. Lustig RH: Childhood obesity: behavioral aberration or biochemical drive? Reinterpreting the First Law of Thermodynamics. Nat Clin Pract Endocrinol Metab 2006, 2:447-458.

10. Ricquier D: Fundamental mechanisms of thermogenesis. $C R$ Biol 2006, 329:578-586. discussion 653-655

II. Levine JA, Kotz CM: NEAT - non-exercise activity thermogenesis - egocentric \& geocentric environmental factors vs. biological regulation. Acta Physiol Scand 2005, I 84(4):309-3 I 8.

12. Henriksson J: The possible role of skeletal muscle in the adaptation to periods of energy deficiency. Eur J Clin Nutr 1990, 44:55-64.

13. Slentz CA, Duscha BD, Johnson JL, Ketchum K, Aiken LB, Samsa GP, Houmard JA, Bales CW, Kraus WE: Effects of the Amount of Exercise on Body Weight, Body Composition, and Measures of Central Obesity. Arch Intern Med 2004, I 64:31-39.

14. Ralt D: Why do we eat? Med Hypotheses 1994, 42:5-10.

15. Hattori K, Kondo M, Abe T, Tanaka S, Fukunaga T: Hierarchical differences in body composition of professional Sumo wrestlers. Ann Hum Biol 1999, 26: I79-184.

16. Andersen LL, Tufekovic G, Zebis MK, Crameri RM, Verlaan G, Kjaer $M$, Suetta $C$, Magnusson $P$, Aagaard $P$ : The effect of resistance training combined with timed ingestion of protein on muscle fiber size and muscle strength. Metabolism 2005, 54:I5I-I 56.

17. Paddon-Jones D, Sheffield-Moore M, Cree MG, Hewlings SJ, Aarsland $A$, Wolfe RR, Ferrando AA: Atrophy and impaired muscle protein synthesis during prolonged inactivity and stress. $\mathrm{J}$ Clin Endocrinol Metab 2006, 9 I:4836-484I.

18. Browning RC, Kram R: Energetic cost and preferred speed of walking in obese vs. normal weight women. Obes Res 2005, I 3:891-899.

19. Le Galliard JF, Clobert J, Ferriere R: Physical performance and Darwinian fitness in lizards. Nature 2004, 432:502-505.

20. Yura S, Itoh H, Sagawa N, Yamamoto H, Masuzaki H, Nakao K, Kawamura M, Takemura M, Kakui K, Ogawa Y, Fujii S: Role of premature leptin surge in obesity resulting from intrauterine undernutrition. Cell Metab 2005, I:37I-I78.

21. Ravelli AC, van Der Meulen JH, Osmond C, Barker DJ, Bleker OP: Obesity at the age of $50 \mathrm{y}$ in men and women exposed to famine prenatally. Am J Clin Nutr 1999, 70:81 I-816.

22. Barker DJ: The developmental origins of well-being. Philos Trans R Soc Lond B Biol Sci 2004, 359: I 359-I 366.

23. Buchan IE, Bundred PE, Kitchiner DJ, Cole TJ: Body mass index has risen more steeply in tall than in short 3-year olds: serial cross-sectional surveys 1988-2003. Int J Obes (Lond) in press. 2006, Aug I

24. Ralt D: The Economics of Obesity and on Low Muscle Mass A special genre of obesity. The Ist World Congress on Controversies in Obesity, Diabetes and Hypertension (CODHy), October 26-29, 2006, Berlin, Germany [http://www.codhy.com/].

25. Thomis M, Claessens A, Lefevre J, Philippaerts R, Beunen G, Malina R: Adolescent growth spurts in female gymnasts. J Pediatr 2005, I 46:239-244.

26. Lindholm C, Hagenfeldt K, Ringertz BM: Pubertal development in elite juvenile gymnasts. Effects of physical training. Acta Obstet Gynecol Scand 1994, 73:269-273.

27. Markou KB, Mylonas P, Theodoropoulou A, Kontogiannis A, Leglise $M$, Vagenakis AG, Georgopoulos NA: The influence of intensive physical exercise on bone acquisition in adolescent elite female and male artistic gymnasts. J Clin Endocrinol Metab 2004, 89:4383-4387.

28. Heude B, Lafay L, Borys JM, Thibult N, Lommez A, Romon M, Ducimetiere $P$, Charles MA: Time trend in height, weight, and obesity prevalence in school children from Northern France, 1992-2000. Diabetes Metab 2003, 29:235-240. 
29. Kain J, Albala C, Garcia F, Andrade M: Obesity in Chilean preschool children: anthropometric evolution and socioeconomic determinants. Rev Med Chil 1998, I 26:27I-278.

30. Korbonits M, Gueorguiev M, O'Grady E, Lecoeur C, Swan DC, Mein $C A$, Weill J, Grossman AB, Froguel P: A variation in the ghrelin gene increases weight and decreases insulin secretion in tall, obese children. J Clin Endocrinol Metab 2002, 87:4005-4008.

31. Gat-Yablonski G, Ben-Ari T, Shtaif B, Potievsky O, Moran O, Eshet R, Maor G, Segev Y, Phillip M: Leptin reverses the inhibitory effect of caloric restriction on longitudinal growth. Endocrinology 2004, 145:343-350.

32. Schwartz MW, Woods SC, Seeley RJ, Barsh GS, Baskin DG, Leibel RL: Is the Energy Homeostasis System Inherently Biased Toward Weight Gain? Diabetes 2003, 52:232-238.

33. Cowley MA, Pronchuk N, Fan W, Dinulescu DM, Colmers WF, Cone RD: Integration of NPY, AGRP, and Melanocortin Signals in the Hypothalamic Paraventricular Nucleus: Evidence of a Cellular Basis for the Adipostat. Neuron 1999, 24:155-163.

34. Nawrocki AR, Scherer PE: The delicate balance between fat and muscle: adipokines in metabolic disease and musculoskeletal inflammation. Curr Opin Pharmacol 2004, 4:28I-289.

35. Seeley RJ, D'Alessio DA, Woods SC: Fat hormones pull their weight in the CNS. Nat Med 2004, 10:454-455.

36. Turtzo LC, Marx R, Lane MD: Cross-talk between sympathetic neurons and adipocytes in coculture. Proc Natl Acad Sci USA 200I, 98:I2385-I2390.

37. Dulloo AG: Regulation of fat storage via suppressed thermogenesis: a thrifty phenotype that predisposes individuals with catch-up growth to insulin resistance and obesity. Horm Res 2006, 65(Suppl 3):90-97.

38. Nemet D, Barkan S, Epstein Y, Friedland O, Kowen G, Eliakim A Short- and long-term beneficial effects of a combined dietary-behavioral-physical activity intervention for the treatment of childhood obesity. Pediatrics 2005, II5:e443-449.

39. US Preventive Services Task Force: Screening and Interventions for Overweight in Children and Adolescents: Recommendation Statement. Pediatrics 2005, I I 6:205-209.

40. Nemet D, Berger-Shemesh E, Wolach B, Eliakim A: A combined dietary-physical activity intervention affects bone strength in obese children and adolescents. Int J Sports Med 2006, 27:666-67I.

41. Westerterp KR: Diet induced thermogenesis. Nutr Metab (Lond) 2004, I:5.

42. Wolfe RR: The underappreciated role of muscle in health and disease. Am J Clin Nutr 2006, 84(3):475-82.

43. Watts K, Jones TW, Davis EA, Green D: Exercise training in obese children and adolescents: current concepts. Sports Med 2005, 35:375-392

44. Benjamin HJ, Glow KM: Strength Training for Children and Adolescents. The physician and sportmedicine 2003, 31:9 [http:// www.physsportsmed.com/issues/2003/0903/benjamin.htm]

45. Faigenbaum AD: Strength training for children and adolescents. Clin Sports Med 2000, 19:593-6I9.

46. Weltman A, Janney C, Rians CB, Strand K, Berg B, Tippitt S, Wise J Cahill BR, Katch FI: The effects of hydraulic resistance strength training in pre-pubertal males. Med Sci Sports Exerc 1986 18:629-638.

47. Shaibi GQ, Cruz ML, Ball GD, Weigensberg MJ, Salem GJ, Crespo $\mathrm{NC}$, Goran MI: Effects of resistance training on insulin sensitivity in overweight Latino adolescent males. Med Sci Sports Exerc 2006, 38: I 208-I2I5

48. Holian CM, King JT, Griffith JR, Adams KJ, Clasey JL: The Effects Of Resistance Training On Measures Of Body Composition And Strength In Children. American College of Sports Medicine 52nd Annual Meeting: I-4 June, 2005; Nashville, Tenn [http://www.abstract sonline.com/viewer/viewAbstractPrint

Friendly.asp? CKey $=\{259 \mid 3$ AD $3-7388-4 F E D-A 8 D A-$

566D25896703\}\&SKey $=\{3$ FI 7|A84-IOAF-4496-855B-

F2CB700F8B3B $\} \& M K e y=\{F 2992993-D 795-4 B C I-94 A E-$ $\mathrm{D} 9440 \mathrm{BF} 33 \mid 4 \mathrm{~A}\} \& A K e y=\{\mathrm{EE} 40 \mathrm{~F} 5 \mathrm{I}$ 4-DBDD-4E5E-B2992E3I2F980A6E\}].

49. Kraemer WJ, Nind BC, Marx JO, Gotshalk LA, Bush JA, Welsch JR, Volek JS, Spiering BA, Maresh CM, Mastro AM, Hymer WC: Chronic resistance training in women potentiates growth hormone in vivo bioactivity characterization of molecular mass variants. Am J Physiol Endocrinol Metab 2006, 29 I:EI I77-I I 87.
50. Marchant $\mathrm{D}$ : Thinking about your muscles makes them stronger. Ref: PR965 British Psychological Society annual conference in Cardiff, UK, 30 March - I April, 2006 [http://www.bps.org.uk/mediacentre/press-releases/releases $\$ /$ anconf06/muscles.cfm].

\section{Pre-publication history}

The pre-publication history for this paper can be accessed here:

http://www.biomedcentral.com/1471-2431/6/33/prepub
Publish with Bio Med Central and every scientist can read your work free of charge

"BioMed Central will be the most significant development for disseminating the results of biomedical research in our lifetime. "

Sir Paul Nurse, Cancer Research UK

Your research papers will be:

- available free of charge to the entire biomedical community

- peer reviewed and published immediately upon acceptance

- cited in PubMed and archived on PubMed Central

- yours - you keep the copyright
BioMedcentral 